\title{
Feature
}

\section{STARS Conference: Student Plenary}

\section{Piper Bell}

Student Voice Australia, Australia

Anna Wilkey

University of Canberra, Australia

Farriz Roslan

Victoria University, Australia

Lincoln James

Deakin University, Australia

Maxwell Willis

University of Adelaide, Australia

Alice Mander

National Disabled Students' Association, New Zealand

\begin{abstract}
The Student Panel Session at the 2021 STARS Conference concluded the formal presentations for the event. At this session, students from the tertiary sector shared with delegates their personal experiences in higher education and thoughts concerning the messages and insights gained from the conference experience. The students had responded to an invitation from Student Voice Australia to participate in the conference, be part of the Panel, and were encouraged to attend the keynote presentations across the event. Delegates had the opportunity to present questions to the students. For the purposes of this feature, the editors have summarised and edited the transcript to present the key points of each discussion, including questions and comments from delegates. Panel members have approved the editorial interpretations of their comments.
\end{abstract}

Keywords: Student voice; higher education; course selection; student experience; disabled students.

\section{Introduction}

The concluding formal session of the 2021 STARS Conference was a student panel discussion, chaired by Professor Ron Oliver, STARS Fellow and Piper Bell, Student Voice Australia (SVA) Coordinator. SVA is currently hosted by the University of Adelaide, Australia under the leadership of the Pro Vice-Chancellor (Student Learning) Professor Phil Levy, and is joined by 16 member institutions working to develop and sustain a culture of student partnership in governance nationally. Working under the guidance of the STEPUP Principles (Varnham, 2017), the SVA develops student, staff, and institutional capabilities to engage in governance and decision-making processes within tertiary education institutions by developing guides and training resources, sharing case studies and exemplars, and connecting staff and student practitioners together through national networking opportunities and events.

The Panel members were Anna Wilkey, Farriz Roslan, Lincoln James, Maxwell Willis, and Alice Mander. Each member had responded to an invitation from Student Voice Australia to join as delegates and then participate in a panel discussion in the 
final plenary session of the Conference. The hosts met with the students prior to the Conference and provided some mentoring and support. This mentoring and guidance for students is indicative of the work and research of SVA which advocates and supports students undertaking representative roles and also because these roles in turn are a key aspect of successful (and meaningful) participation and partnering work.

This summary of the discussion highlights the key aspects of each student's tertiary experience and responds to the key questions and comments from delegates and the Panel hosts.

\section{Piper Bell, Student Voice Coordinator and Student Panel Co-Host}

(joining from Kaurna land and acknowledging the Kaurna people, the original custodians of the Adelaide Plains)

Anna Wilkey is from University of Canberra, studying a Master of Secondary Teaching. Do you want to tell us why you decided to embark on higher education?

\section{Anna Wilkey \\ (joining and acknowledging the lands of the Ngunnawal people)}

I first entered higher education years ago as an 18-year-old who was first in my family to go to university and, for the most part, I haven't actually left, so a decade on and now considered a mature age student, having studied at five different universities.

I'm also a mum to a very active two-year-old so with the impacts of sleep deprivation, I was quite pleased that I remembered that university was actually never not an option for me. In fact, I thought of it as my only post-school option. My mum was a single parent, we lived on a government benefit, and she was also a refugee from the Khmer Rouge regime in Cambodia. She saw tertiary education as the pathway to a better life for my brother and I. All in all, I think my mum did succeed in raising two permanent lifelong learners. So, here I am part-way through one Masters degree, a Master of Teaching, and eagerly starting another one, a Masters by Research. My brilliant supervisors have been encouraging me to think about my positionality and really unpack why I want to study, and why I want to study what I want to study, the topic being critical consciousness and pre-service teacher education.

\section{The value of higher education:}

At 18 I found myself confronted with the realisation that the world is an unequal place, and I think throughout the conference the topic of educational equity was brought up and, as Paulo Freire (1996) would put it, the discovery by the oppressed that they exist in dialectical relationship to the oppressor and that's the 1996 version on page 31, for any eager academic integrity enthusiasts out there, and so attending university was part of that transformation journey, transforming myself into the image of those who I perceived to be my superior kind of being.

Except that, about two weeks ago I realised I've been drinking the bourgeois Kool-Aid and I'm now having apparently a very normal stronghold research student identity crisis. My wonderful supervisors have been very kind to me, they haven't emailed, despite not having heard from me for two weeks. I'm also told that this is this is a very normal part of that identity crisis for disappearance, I'm sure that many supervisors here today probably understand that research student journey. So, education matters to me because it enables me to contribute to the conversation and speak for those young students whose presence is not seen or felt in the higher education space. But also, because in higher education we teach our future teachers, our future politicians, which is very relevant being here in Canberra, our future parents, our future leaders, who will change society for better or worse, and what we do really matters here, and I really love being part of this.

\section{Choosing the right course:}

As a mature age student, I'm now in a position where I am able to look through courses and choose them on my own and I understand how all that works for me in the back end. I remember being a first-year student, coming from a school where the 
majority of my peers hadn't chosen university as their post-school pathway, so, everything was new to me. I had excellent support in terms of course advisors who were able to sit down and direct me as to what I needed to do in order to fulfill their requirements.

\section{A particular keynote that spoke to any of you of something of particular importance:}

It was the first keynote (Simon Marginson) and that conversation about university and the public good really stood out for me and really spoke to why I'm here, and I'm sure that probably really resonates with you as well.

\section{Piper Bell}

Farriz, you're coming from Victoria University, and you're an international student from Singapore. You're studying law - do you want to tell us more about your journey to university?

\section{Farriz Roslan}

(joining and acknowledging the lands of the Boonwurrung, Wadawurrung and Wurundjeri of the Kulin)

Before I entered university, I was a police officer, that's when I served in national service in Singapore. That sparked my interest in law, to take on a Bachelor of Laws. When I first entered higher education, I just thought of getting a job out of it, just graduate and become a lawyer but after three years of being there, it changed immensely, and I realised that now I want to stay in higher education because of the change I can create. Being involved in the Student Voice Network is quite fulfilling to me as well as a university student to see that universities are taking the initiative to provide change.

\section{The value of higher education:}

Why education matters here is to create change. Whether it be diploma, masters, $\mathrm{PhD}$, bachelors, you're creating change in the society. Education means so much to me because as an international student as well the diversity and the conclusion means a lot to me. I was glad to see that in one of the presentations there was a session talking about suicidal Chinese students, talking about the tension that international students face. And I relate a lot to that - education is about changing, but it's also about understanding and about seeing a different perspective that we never would have seen because we are not the person who's suffering, and this goes a very long way and we see that societal change whether it be in the LGBTQ community, whether it be the Aboriginal community, there's so much change and that's why higher education is so important and that's why education in general is so important is because we want to understand, we want to make a difference whether it be locally or globally. And that's why I'm here in the university and why I'm speaking and advocating for students, because it is for the betterment of the future.

The great thing about being in higher education is the research, the skills that you've attained regardless of whether it's science or economics or architecture or for myself in a Bachelor of Laws. You develop skills that allow you to research, it allows you to understand, allows you to be open-minded, it allows you to get so much information and apply it to the real life world. How do we change? And yes, I might be more educated in law than, for example, a science student, but the level of skills that we attain, the level of open-mindedness is why the world is changing to what it is at the moment and why it's continuing to change. That's what I think is really important. What society needs to understand is that a Bachelor of Laws doesn't only mean Bachelor of Laws, university means education and education means change.

\section{Piper Bell}

Lincoln, you're doing your $\mathrm{PhD}$ and working at Deakin University, so you've got an interesting perspective on life within the institution, do you want to share that with us?

\section{Lincoln James}

(joining and acknowledging the lands of the Wurundjeri and Boon Wurrung people of the greater Melbourne region)

I came to university a bit later in life, so before I came to Deakin as an undergrad I was bouncing around in hospitality and it was a great time and I don't want to disparage the people that work in hospitality, but I looked at my managers and I thought, 
you're nice people but I really don't want to be you, I don't want to be in your job. It still took me a very long time to figure out what it was I wanted to do, so now I'm in higher education, I'm researching higher education. It was so great to be able to dip into different disciplines and just figure out what it was that I was passionate about and I eventually realised that it was the higher education experience that I was so passionate about. I found it to be incredibly transformative and it just opened my eyes to different ways of thinking, and to things that I didn't even really know existed. I think that being 22 when I came to university made my university experience better for me, I was perhaps able to make choices, in a more informed way that not every 18 year-old is perhaps at the same position to be able to make, and so part of what I would like to do with my $\mathrm{PhD}$ is be able to help universities support younger students to be able to make similarly informed and proactive choices about their own time at university and, hopefully about their own future lives and careers in preparation for whatever they're going to do post university.

\section{The value of higher education:}

Have a look at what's happening in America and look at what happens when you systematically degrade an education system both in what's the compulsory part of education, and then when you make university education so freaking expen sive, and so inaccessible. Look at what happened when what's-his-name got elected in 2016. We don't want that to happen in Australia. And so, universities are so essential for a functioning democracy to fight injustice, to lift those who are struggling and those who have faced immense challenges, and to help them have a better life. My mum was also a first-generation migrant, she moved here from Singapore, and she had to make many sacrifices as a single parent so that I could have the opportunity to focus on my studies. I want to make sure that every other student is able to get the most out of their university studies and I'm lucky that my mum was making those sacrifices so that I could focus on my studies. I hope that every other student that wants to come to university is able to focus and get the most out of their university experiences.

I also teach in a first-year career education unit called 'Professional Insights' so that's one of the first questions I ask my students, why have you chosen to study? A lot of the time they don't know, or it's, 'my parents have wanted me to become an accountant' or some other permutation of that. I wonder if we should be pushing off a little bit of the responsibility for this, onto high schools and saying can you please do a little bit more career education with your students? The extent of career education with high school students shouldn't just be you're really good at maths and science you might get a high ATAR therefore you can go and do medicine. It should be a little bit more complex than that so that students can be making informed choices about their future studies and their future lives before they even get to universities. Students may only be at university for three years, that's a very short time for them to be making decisions about the rest of their lives and universities can't be doing everything.

\section{Enabling the student voice in higher education:}

I'm doing a PhD, I also do learning design and teaching (in a staff capacity) and so I know that as a student, especially as an undergrad, the university staff looks like this kind of unified edifice, it just looks really intimidating and now that I work on the other side I can see it's really not that, and so it can sometimes look like the students don't have a voice but to any of those people that are feeling like they don't have a voice reach out to academics, it can be scary but I recommend just keep being noisy. And if you're advocating for your students, be noisy on their behalf. Be that squeaky door, be so annoyingly squeaky that management has to oil you down to solve that issue because it's absolutely horrible that a student's internship is one week away from completion when perhaps you could be having a conversation on how you can we work around that rule, could it be done virtually? Can it be done in a different way? Can it be done in the community? Be squeaky because you know that sitting there and taking it doesn't really get you anywhere.

\section{What defines student success?}

I think in many ways that definition should be driven by the individual students. I think that our students should be defining what success looks like for them, but we should absolutely be helping them to define what success looks like for them.

\section{A particular keynote that spoke to you of something of particular importance:}

Perhaps I'm being loyal because Jane dan Hollander was my VC, but her message on reimagining the curriculum was really powerful. I think sometimes we tend to work in silos with our teaching a bit too often and so reimagining maybe isn't so much reimagining as it is just collaborating and taking these pockets of excellence and spreading them across the university because, you know, there's already amazing things happening it's just about sharing them. 


\section{Piper Bell}

Max joins us from the University of Adelaide. Do you want to explain to everybody about the reason that you entered higher education, and why your education matters to you?

\section{Maxwell Willis}

(joining and acknowledging the lands of the Kaurna land)

It really started off in high school. In my first few years of high school I gained a passion for science. I became fascinated with the industry of science and that science with the scientific method could improve the way humans live. I learned that science could be used to produce findings that help us live more sustainably, that help us live longer, and with improved quality of life, and science could really be used to create a society in which all human needs are I suppose, secured in the long term. I went online and looked for what a career in science could offer, and I found that through a career in science I could fill my time with a fascinating job and earn a living as well as contribute positively to society. I looked at what qualifications are needed for a career as a scientist and found that most roles require a Bachelor of Science degree as a minimum. I also found that many roles also require a postgraduate qualification such as a masters or a $\mathrm{PhD}$, according to the level of expertise that is desired for the role. In light of this, I decided I would apply for a Bachelor of Science degree as it seemed to be the necessary first step in pursuing my career as a scientist.

\section{The value of higher education:}

I think, there is a misconception that when you do a university degree it gives you the job that you had in mind when you applied for that university degree, and I think there is a misunderstanding that there is only a limited set of jobs that you can apply for with a given degree. When you do a degree in science or engineering not only do you gain skills and understanding specific to a subject like environmental science, physics, chemistry, biology, you also gain analytical skills and research skills that you can apply to a wide range of jobs that you may be applying for.

What I found that has been very helpful are skills such as scientific communication and professional communication, ethics and an understanding of ethics, an understanding of intercultural issues and an understanding of how to treat people with respect and be empathetic as well as providing skills specific to science such as the scientific method and academic rigor and things like that. I think university does do quite a good job of this in my opinion, providing us with general and thorough and extensive training for professional life.

\section{The quality of teaching and the learning experience:}

In our earlier conversations prior to this panel, we talked about one of the current issues in universities at the moment which are online assessments and the way that assessments are designed to be delivered online.

Drawing on some of the other presentations that have been given in previous days, in this conference, I would really like to encourage academics and staff who design assessments to go back to the drawing board and think about the purpose of assessments and what are we trying to achieve through assessments. Are we trying to measure to what extent a student can demonstrate the knowledge and skills they've acquired through the course? Are we trying to assess how ready a student is to fulfill a certain role in the workforce? For example, how capable are they at doing ' $x$ ' ' $y$ ' and ' $z$ ' procedures which they'd be expected to do in industry, and think about whether our exams are a good way to evaluate what we're trying to evaluate? Are written assignments a better way? Are practical exams a better way? And if so, is it realistic to give a student only three hours to demonstrate their knowledge and skills in an environment where they can't access certain resources? Whereas maybe in industry they would be allowed to access certain resources. Would it be more fair or more realistic, and provide us with better measures, if we had a take-home exam that we could do over the course of a few days - and access resources that would be accessible in the real world? It's a difficult issue, it's a difficult problem, I'm glad it's not my problem, because you know I personally wouldn't know what the perfect solution is. 


\title{
Piper Bell
}

Alice joins us all the way from New Zealand today. Alice, you are doing a double degree in arts and law, and you are the president and founder of the National Disabled Students Association, do you want to tell us about your journey?

\begin{abstract}
Alice Mander
Kia Ora everyone. When I left high school I was in the position where going to university was honestly just the only path forward. That was kind of the expectation so, at that point I didn't really think about it too much. But after a couple of years at being at university and sort of finding my passions and what I liked, I realised that this is the space where we really can recognise what's going on in society. And so, I think, as a disabled woman, this is where I really became kind of socially conscious of everything that's going on around me. And I think that's why I love and entered higher education.
\end{abstract}

\section{The value of higher education:}

In history we've seen social movements start at the academic level, for example, with feminine race theory, with disability studies, which is where my sort of passion is in law at the moment. So, we really see that all these social movements come from ideas and those in this brilliant institution that is the university. I guess that kind of connects to the other reason that I think higher education is so important, and that's that it's a community and it's really been about creating a community, whether that be student associations, women's groups, places where minorities can engage in consciousness raising. For myself it's been the disabled students' groups and we've really had the chance to connect and really get to know ourselves on a more politicised, but also academic and social. level and I think that's really invaluable and also allows us to see others in a different light. That's why our education is so important. And that's also why I think the work that students do to make university more equitable is also so important because while we know that the higher education space is all about social change and social movement, it is still at that elitist academic level to be frank.

I think there is a responsibility and an obligation to really work towards creating more equitable environments in higher education for students and staff who might not otherwise be able to participate. I just think higher education is an opportunity to really see the world in a different way and to get yourself out there as well. I'm doing my honours thesis in disability and disability law, and I read a book by Michael Oliver, who's a famous disability studies academic, and he said that when we research, we're not only trying to understand the world but we're trying to put ourselves into the world and also put ourselves into research. I think that's what I really love about higher education.

\section{Universities' responsibilities and upholding the rights of students with disabilities:}

I can only speak about New Zealand, but we know that universities aren't meeting their obligations under the UN Convention on the Rights of Persons with Disabilities (UNCRPD). There is actually a need for a recommendation by the regulatory body that universities have to make tertiary education more accessible for disabled people. I'm seeing a lot of space where there's a great deal of structural inaccessibility, whether that be actual physical accessibility or the way that education in itself has been structured historically, which has been to make the disabled person's body and mind into the 'other'. My advice would be to listen to disabled students because they know best about both their education and their needs, and I think we're kind of in a state where currently, at least in New Zealand, a lot of the time, disability support is sacrificed.

Disabled students aren't getting their voices heard and in the disabled rights movement we have a motto that's 'nothing about us without us' and that goes for students as well. I think tertiary education providers have this idea that the issues facing disabled students are just a funding issue, which is true to an extent as there are a lot of services that are being underfunded in the tertiary space. What we've found here in New Zealand in speaking to students is that if providers actually listen to their disabled students, the students themselves have fantastic and creative innovative ways of solving these issues that don't require more money, they just require a different approach. I think that's an example of how strong and important it is to have partnership with your students.

Not only do disabled people have a right to an education but they also have a right to an education that's supposed to enhance their, in New Zealand we call it 'mana', so it's supposed to enhance their sense of self. And I think in the tertiary space for the most part we're still not seeing that, we're still seeing a very heavy medical model within tertiary education and with that you know we see the individualisation of disability rather than the celebration of it. I think tertiary spaces and academics could learn 
a lot from their fellow disability studies academics, as well as other minorities. The feminist movement has a lot to say like queer theory. And by doing that and by including more of that in your curriculum, you're saying to the one or two disabled students in your class, you know we listen to you, we hear you and we see you as more than just a medical problem, we see you as a person and I think that is crucial.

\section{The value of interdisciplinary experiences:}

Interdisciplinary experiences are really important. I think that's why I love the arts degree in New Zealand because it really does provide that sort of holistic education where you don't just get the black and white stuff, you get emotive things, there's different analysis from different perspectives, and different groups of people as well and I think that's really crucial, especially for some of these professional degrees like law or engineering, some of these degrees. It is so important that we are training our future professionals who will be dealing with people on a face-to-face basis to have the basic people-skills, to understand a bit of social theory, a bit of feminist theory, a bit of critical race theory that's going to be so crucial for when they're really engaging with people face-to-face. It also teaches us how to work together because we're never going to be really working on our own, you're always going to have to work with others.

\section{What defines student success?}

To find the answer you really need to partner with your students and to hear your students in a way that's really meaningful. Because without that, you're never going to reach success unfortunately. It goes back to my point before that often providers think it's a funding issue but often it actually is just about listening to the right people or taking the right path. It's really important that universities are putting energy and resources into the right type of student success. To find that out you only have to turn and ask your students, so that's the challenge.

\section{Acknowledgment from STARS}

The STARS Team congratulate Anna Wilkey, Farriz Roslan, Lincoln James, Maxwell Willis, and Alice Mander for their successful participation in the Conference. We acknowledge and thank STARS Fellow Professor Kerri-Lee Krause for introducing the student session, and Professor Ron Oliver, STARS Fellow and Piper Bell, Student Voice Australia Coordinator, for organising and hosting the 2021 Plenary session.

Also, the Team thank Rosie Blanch from the Office of Scholarly Communications, QUT Library for transcription support.

\section{References}

Freire, P. (1996). Pedagogy of the oppressed. Penguin

Varnham, S. (2021). Creating a national framework for student partnership in university decision-making and governance. https://studentvoiceaustralia.com/principles/

Please cite this article as:

Bell, P., Wilkey, A., Roslan, F., James, L., Willis, M., \& Mander, A. (2021). 2021 STARS Conference: Student Plenary. Student Success, 12(2), 1-7. https://doi.org/10.5204/ssj.2060

Student Success: A journal exploring the experiences of students in tertiary education

(c) (i) Except where otherwise noted, content in this journal is licensed under a Creative Commons Attribution 4.0 International Licence. As an open access journal, articles are free to use with proper attribution. ISSN: 2205-0795 